\title{
Analisis Perilaku Legislator Dalam Perencanaan Kesehatan Di Kabupaten Bantaeng
}

\section{Analysis of Legislator Behavior in Health Plannimg at Bantaeng Regency}

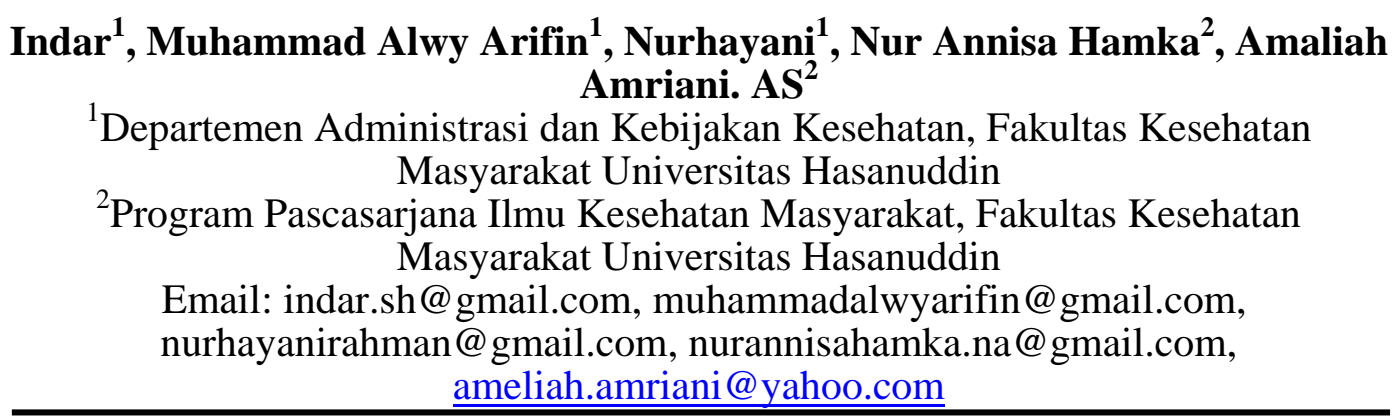

\begin{abstract}
ABSTRAK
Kesehatan merupakan investasi untuk mendukung pembangunan serta memiliki peran penting dalam upaya penanggulangan kemiskinan. Pembangunan kesehatan harus dipandang sebagai suatu investasi untuk meningkatkan kualitas sumber daya manusia. Tujuan dari penelitian ini untuk menganalisis perilaku legislator dalam perencanaan kesehatan di Kabupaten Bantaeng. Kabupaten Bantaeng dipilih karena Kabupaten Bantaeng merupakan salah satu daerah di Provinsi Sulawesi Selatan yang memiliki Dana Alokasi Umum tertinggi. Jenis penelitian ini merupakan penelitian kualitatif. Pengumpulan data dilakukan dengan menggunakan metode wawancara mendalam (indepth interview), observasi dan telaah dokumen. Pengolahan data dilakukan menggunakan triangulasi dan metode content analisys. Hasil penelitian diketahui bahwa berdasarkan indikator pengetahuan, legislator berada pada kategori kurang, disisi lain, indikator sikap, persepsi dan tindakan legislator terhadap perencanaan kesehatan berdasarkan wewenangnya sudah baik, selain itu diketahui bahwa terdapat kepentingan legislator dalam hal perencanaan kesehatan namun kepentingan tersebut untuk mengakomodasi kepentingan derajat kesehatan masyarakat Kabupaten Bantaeng.
\end{abstract}

Kata kunci: Perilaku, Legislator, Perencanaan Kesehatan.

\begin{abstract}
Health is an investment to support development and has an important role in poverty alleviation efforts. Health development should be seen as an investment to improve the quality of human resources. The purpose of this study to analyze the behavior of legislators in health planning in Bantaeng Regency. This research was conducted in Bantaeng Regency with consideration that Bantaeng Regency is one of the regions in South Sulawesi Province that has the highest General Allocation Fund. This research used qualitative aprroach. Data collection is conducted using indepth interview method, observation and document study. Data were analyzed using tringulation and content analisys method. The results of the study are known that based on knowledge indicators, legislators are in the "less" category, on the other hand, indicators of attitudes, perceptions and actions of legislators to health planning based on their authority is good, in addition it is known that there is an interest of legislators in terms of health planning but the interest is to accommodate the interests of the public health in bantaeng.
\end{abstract}

Keywords: Behavior, Legislator, Planning 
Indar, Muhammad Alwy Arifin, Nurhayani, Nur Annisa Hamka, Amaliah Amriani. AS : Analisis Perilaku Legislator Dalam Perencanaan ....

\section{PENDAHULUAN}

Kesehatan merupakan investasi untuk mendukung pembangunan serta memiliki peran penting dalam upaya penanggulangan kemiskinan. Dalam pengukuran Indeks Pembangunan Manusia (IPM), kesehatan adalah salah satu komponen utama selain pendidikan dan pendapatan sesuai dengan yang diamanatkan oleh Undang-Undang Nomor 36 tahun 2009 tentang Kesehatan ditetapkan bahwa kesehatan adalah keadaan sejahtera dari badan, jiwa dan sosial yang memungkinkan setiap orang hidup produktif secara sosial dan ekonomi (Kemenkes RI 2009). Perencanaan kesehatan erat kaitannya dengan pembiayaan dan analisis situasi kesehatan. Implementasi Undang-undang No 19 tahun 1999 menjadi Undang-Undang No.23 Tahun 2014 tentang Pemerintah Daerah secara kongkrit berdampak terhadap kewenangan pemerintah daerah termasuk dalam perencanaan pembangunan kesehatan.

Salah satu yang paling berperan dalam merumusakan arah kebijakan pembanguan dalam suatu daerah khususnya dalam Perencanaan kesehatan adalah para pemangku jabatan dalam lingkup legislatif yang dikenal sebagai wakil-wakil rakyat yang terpilih duduk di Dewan Perwakilan Rakyat Daerah atau disebut juga legislator. Hal ini ditegaskan pada pasal 42, UU No 23 Tahun 2004 yang menyatakan bahwa: (1) DPRD mempunyai tugas dan wewenang membentuk peraturan daerah yang dibahas dengan kepala daerah untuk mendapatkan persetujuan bersama. (2) DPRD membahas dan menyetujui rancangan peraturan daerah tentang APBD bersama dengan Kepala Daerah.

Dewan Perwakilan Rakyat Daerah Kabupaten Bantaeng adalah Lembaga perwakilan rakyat daerah tingkat kabupaten yang ada di Kabupaten Bantaeng, Provinsi Sulawesi Selatan. DPRD Bantaeng memiliki 25 anggota yang tersebar di 9 partai politik. Ada beberapa persoalan substantif yang terjadi di DPRD Kabupaten Bantaeng berdasarkan fenomena yang terjadi dalam praktik proses legislasi antara lain: lahirnya perda yang tidak aspiratif sehingga mengundang protes dari warga masyarakat, keterbatasan keterlibatan tenaga ahli, partisipasi publik atau RDPU yang belum terjamin dan idak adanya lembaga riset pendukung dalam bidang layanan publik dan bidang kesehatan.

Persoalan kebijakan kesehatan dan proses perencanaan kesehatan tidak semuanya berjalan sesuai dengan harapan, khususnya yang ada di daerah, alokasi anggaran kesehatan cenderung minim, realisasi program kesehatan yang tidak berjalan, persoalan SDM yang erat kaitannya dengan kepentingan para elite, perencanaan kesehatan dan evaluasi yang tumpang tindih atau terabaikan merupakan persoalan politik kesehatan 
yang erat kaitannya dengan para pembuat kebijakan dalam perencanaan kesehatan salah satunya adalah para legislator dalam konteks politik merupakan salah satu aktor pembuat kebijakan yang memegang peran dalam memutuskan kebijakan publik termasuk bidang kesehatan (Ariyanti, 2017). Kesemuanya dapat dilihat dari bagaimana keberpihakan para legislator baik yang ada dipusat khusunya yang ada di daerah berdasarkan pada perilaku yang merupakan representatif dari keputusan- keputusan kebijakan dalam perencanaan kesehatan dan realisasi amanah Undang-Undang sebagai aturan yang wajib untuk menjadi tanggung jawab (Handoko, 2016).

Ramadhan (2012) menyatakan dalam penelitiannya tentang interaksi kepentingan eksekutif dan legislatif dalam perencanaan kesehatan bahwa faktor yang mempengaruhi terhadap perencanaan kesehatan adalah kepentingan yang ada didalmnya yang menguntungkan satu sama lainnya yang bersumber dari perilaku yang muncul dari eksekutif dan legislatif. Lebih lanjut, penelitian oleh Irawan (2014) dalam analisis perilaku legislatif dan eksekutif terhadap perencanaan kesehatan di kota langsa menunjukkan bahwa kurangnya pengetahuan dan sikap serta besarnya kepentingan setiap anggota komisi dalam DPRD membuat alokasi anggaran kesehatan dibawah $10 \%$ atau sekitar 5,8\%.

Perilaku, menurut Benyamin Bloom, dapat dilihat dari tiga Unsur penting yang dimiliki oleh individu dalam interaksinya terhadap suatu objek yang sedang atau dilakukan yaitu, tingkatan pengetahuan individu, sikap yang dimiliki oleh individu dan tindakan yang dilakukan dalam menangani respon, tindakan dapat dilihat dari aspek persepsi sebagai bentuk pemahaman terhadap suatu objek tertentu. Keadaan tersebut salah satunya disebabkan oleh lemahnya perencanaan kesehatan sebagai akibat dari kurangnya advokasi dinas kesehatan dalam perencanaan program-program kesehatan, yaitu adanya perbedaan yang menyolok antara usulan program dengan program yang disetujui dan direalisasi pengambil keputusan, stakeholder dan legislator sebagai salah satu pemegang mandat dalam mensejahterahkan masyarakat di daerahnya (Fitriany, Farouk, \& Taqwa, 2016). Berdasarkan latar belakang masalah diatas maka peneliti termotivasi dan bermaksud melakukan penelitian dan kajian terhadap masalah dalam, Analisis Perilaku Legislator dalam Perencanaan Kesehatan di Kabupaten Bantaeng Tahun 2021. 
Indar, Muhammad Alwy Arifin, Nurhayani, Nur Annisa Hamka, Amaliah Amriani. AS : Analisis Perilaku Legislator Dalam Perencanaan ....

\section{METODE}

Jenis penelitian ini merupakan penelitian kualitatif yang merupakan metode penelitiannya dilakukan pada kondisi alamiah (natural setting), karena data yang terkumpul dan analisisnya lebih bersifat kualitatif. dimana hasil penelitian ini lebih berkenaan dengan interpretasi terhadap apa yang ditemukan di lapangan. Penelitian ini dilakukan di Kabupaten bantaeng. Sumber Informan dalam penelitian ini ditentukan dengan secara sengaja atau snowball sampling, terdapat sebanyak 5 informan. Dalam penelitian ini sumber data dipilih, dan mengutamakan perspektif emik yang artinya mementingkan pandangan informan yaitu data primer dan sekunder. Analisis data penelitian ini menggunakan analisis isi (Content Analysis).

\section{HASIL}

Penelitian ini merupakan penelitian kualitatif yang bertujuan untuk menganalisis Perilaku legislator dalam perencanaan kesehatan di Kabupaten Bantaeng Tahun 2021, dilihat dari aspek pengetahuan, sikap, persepsi, tindakan dan kepentingan legislator dalam proses perencanaan kesehatan. Penelitian ini dilaksanakan pada bulan mei sampai juli 2021 di Kabupaten Bantaeng. Adapun karakteristik informan yang terlibat dalam penelitian tentang perilaku legislator dalam perencanaan kesehatan di Kabupaten Bantaeng tahun 2021:

Tabel 1. Karakteristik Informan Penelitian

\begin{tabular}{lccccc}
\hline No & $\begin{array}{c}\text { Kode } \\
\text { Informan }\end{array}$ & $\begin{array}{c}\text { Umur } \\
(\text { Thn })\end{array}$ & Jabatan/ Komisi & $\begin{array}{c}\text { Pendidikan } \\
\text { Terakhir }\end{array}$ & Daerah \\
\hline 1 & H & 38 & Ketua DPRD & D3 & Kab. Bantaeng \\
2 & MAB & 41 & Ketua Komisi III & S1 & Kab. Bantaeng \\
3 & HA & 42 & Anggota Komisi III & D3 & Kab. Bantaeng \\
4 & AU & 50 & Ketua Komisi II & S1 & Kab. Bantaeng \\
& & & (Badan Anggaran) & & Kab. Bantaeng \\
\hline
\end{tabular}

Terdapat 5 informan yang terdiri dari Ketua DPRD Kabupaten Bantaeng,

ketua komisi III, anggota komisi III, ketua komisi II, dan anggota komisi I. Adapun berikut merupakan penyajian data hasil penelitian yang disajikan secara deskriptif oleh peneliti.

\section{Pengetahuan}

Berikut merupakan kutipan hasil wawancara yang dilakukan oleh peneliti, terkait keberadaan data yang dipakai dalam realisasi perencanaan bidang kesehatan:

"Kalau perencanaan jelas datanya, apalagi kebetulan kami bermitra dengan dinas kesehatan tentu sangat berat, karena mitra terkait itu sama-sama sensitif, sama- 
sama kooperatif dalam bermitra dengan kami. Setiap ada update, ada data-data terbaru, mereka laporkan baik secara lisan maupun secara tertulis.." (MAB, 41 Tahun)

Pengetahuan informan terhadap tahap dan proses perencanaan kesehatan terlihat tidak begitu memahami proses perencanaan kesehatan sesuai dengan tahapan perencanaan kesehatan mulai dari analisis situasi, identifikasi masalah, penentuan prioritas masalah, hingga penentuan alternatif pemecahan masalah, dan dapat di interpretasikan pengetahuan berada di level standar, karena hanya mengetahui proses perencanaan dari apa yang legislator hadapi di lapangan yaitu penyediaan data sebagai latar belakang perencanaan program kesehatan yang akan legislator bicarakan lebih lanjut terkait alokasi anggaran programnya.

\section{Sikap}

Dari hasil wawancara mendalam dengan Informan maka Respon dalam hal perencanaan kesehatan berdasarkan sikap para legislator tentang perencanaan kesehatan di Kabupaten Bantaeng:

"Eee... pokonya, intinya kita di sini, karena kita mewakili masyarakat banyak, apapun itu. Jangankan dari dinas kesehatan, tapi karena ini dinas kesehatan pada khususnya, apapun itu kalau memang itu outputnya, incomenya semua untuk masyarakat yang banyak bagus, positif, kita pasti support, iya..” (HA, 42 Tahun)

"Eee... kita pelajari dulu, programnya. Apakah betul-betul program yang dicanangkan pemerintah daerah itu betul-betul langsung mengena ke masyarakat, tujuannya ini jangka pendek, jangka panjang, terus kita diskusikan dengan temanteman komisi." (MII, 28 Tahun)

"Alhamdulillah, coba kita bandingkan dengan kabupaten lain, waktu sebelum lebaran, sebelum puasa, luar biasa ini dinas kesehatan bekerja di perbatasan itu. Makanya tren eee... Covid, jumlah covid itu sering ditekan. Dia mampu keluar dari, ketika dia bisa maksimal, dia bisa turunkan. Apalagi kalau kencang anggarannya, aduhh." (MAB, 41 Tahun)

Respon berdasarkan sikap para legislator tentang perencanaan kesehatan di Kabupaten Bantaeng yang dimulai dari tahap analisis situasi, prioritas masalah, penetapan alternatif, penetapan tujuan, penetapan program hingga tahapan penilaian berperan aktif dan menerima dengan baik masukan yang ada.

\section{Persepsi}

Dari hasil wawancara mendalam dengan Informan maka persepsi para legislator tentang perencanaan kesehatan di Kabupaten Bantaeng:

“...Jadi kita bersama-sama mereka, kita survei mana yang layak, mana yang tidak. Jadi memang intervensi itu kita lakukan, kita maksimalkan. Khususnya juga di pengadaan obat yang prioritas, yang jelas mereka sudah analisa sedini mungkin, 
Indar, Muhammad Alwy Arifin, Nurhayani, Nur Annisa Hamka, Amaliah Amriani. AS : Analisis Perilaku Legislator Dalam Perencanaan ....

sejauh mungkin. Tapi tetap kita secara proporsional masuk, sesuai dengan hak anggaran kita. Rasionalisasi dan kesepakatan kita, dan tidak secara otoriter, tidak secara...tetap kita berdiskusi, kita kedepankan itu demokratif antara mitra kerja" (MAB, 41 Tahun)

"eee... di dinas kesehatan, dianggarkan misalnya satu juta, ternyata karena pandemi jadi dibtuhkan lebih daripada itu..... Ya.. disinilah tugasnya kita DPR, bagaimana kita support dari Banggar supaya dikasi dana khusus atau ditambahkan dananya, seperti itu. Supaya hasilnya itu kan, bagus kan, seperti itu. (HA,42 Tahun)

Informan mempunyai persepsi bahwa usulan anggaran terhadap program kesehatan yang telah diusulkan cenderung tidak semua disetujui dan disahkan oleh legislator, mengingat terbatasnya alokasi anggaran dari APBD atau APBN, sehingga tidak mampu mengakomodir seluruh usulan-usulan program kesehatan dalam perencanaan kesehatan dari dinas kesehatan. Untuk itu, kadang-kadang dilakukan rasionalisasi data untuk melihat manakah program yang merupakan prioritas dan perlu alokasi dana lebih.

\section{Tindakan}

Dari hasil wawancara mendalam dengan Informan maka wewenang legislatorterkait tindakan para legislator tentang perencanaan kesehatan di Kabupaten Bantaeng:

“.......Jadi kita harus bertanggungjawab, tetapi peran untuk mengatur yang secara eee... tersendiri yang dilakukan oleh legislator belum ada regulasi sampai saat ini yang saya lihat untuk seperti itu, tapi suporternya itu tetap ada kepada dinas terkait. Sentuhan langsung ke perencanaan kesehatan tidak ada, pengawasan ada..” (H, 38 Tahun)

Pemahaman mengenai tindakan langsung yang dilakukan dalam rangka wewenangnya sebagai legislator dengan tugas-tugas dan fungsinya, dapat diintrepretasikan bahwa tindakannya tersebut sudah pada penerapannnya.

\section{Kepentingan}

Seluruh Informan pada umumnya menyatakan bahwa kepentingan tidak dapat terlepas dari segala aktivitas legislator, tetapi jika dibandingkan dengan kepentingan masyarakat, prioritas kepentingan pribadi berada diurutan terbawah hal ini terlihat dari hasil wawancara dengan informan sebagai berikut:

"Saya rasa kalau kepentingan memang tidak bisa dipisahkan dengan dunia politik. Tapi, lagi-lagi kita kedepankan kepentingan umum, terus terang.. untuk apa kita bekerja, kita diberi amanah oleh rakyat, kalau kita dahului kepentingan pribadi........" (MAB, 41 Tahun)

"Ada, sangat ada. Kalau prioritasnya, skala prioritasnya bukan untuk kepentingan masyarakat." (AU, 50 Tahun)

Dari hasil wawancara beberapa informan menganggap kepentingan masyarakat 
menjadi prioritas utama, akan tetapi masih terdapat beberapa informan yang menganggap bahwa kepentingan individu itu ada dan kepentingan kelompok dalam hal ini konstituen dan partai politik sebagai kendaraannya masuk menjadi anggota dewan perwakilan rakyat di daerah sehingga masih menjadi bagian penentuan kebijakan, termasuk program bidang kesehatan yang dibahas dalam perencanaan kesehatan dan anggaran kesehatan daerah.

\section{PEMBAHASAN}

Pengetahuan sangat erat kaitannya dengan pendidikan, seseorang dengan pendidikan tinggi, maka orang tersebut akan semakin luas pula pengetahuannya (Rahman, 2017). Dengan kata lain, semakin banyak informasi yang masuk semakin banyak pula pengetahuan yang didapat dalam hal ini tentang kesehatan. Namun perlu ditekankan bahwa seorang yang berpendidikan rendah tidak berarti mutlak berpengetahuan rendah pula. Peningkatan pengetahuan tidak mutlak diperoleh di pendidikan formal, akan tetapi juga dapat diperoleh melalui pendidikan non formal.

Pengetahuan informan terhadap tahap perencanaan di Kabupaten Bantaeng masih berada pada kategori kurang mengetahui tahapan perencanaan secara sistematis mulai dari keperluan data sebagai bahan awal sampai tahap evaluasi di masyarakat. Dilihat dari aspek-aspek yang yang digunakan untuk menilai pengetahuan legislator, pendidikan tidak memiliki pengaruh yang signifikan terhadap pengetahuan informan, hal ini dipengaruhi oleh masa kerja yang dimiliki oleh informan, dimana ada informan yang memiliki pendidikan yang lebih rendah tetapi masa kerjanya lebih lama sehingga mengetahui tahapan perencanaan kesehatan lebih baik dibandingkan dengan yang memiliki tingkat pendidikan yang lebih tinggi tetapi masa kerjanya belum mencapai satu periode. Hasil ini sejalan dengan penelitian Bakri (2017) yang mengatakan bahwa pengetahuan, dapat diperoleh dari pengalaman baik dari pengalaman pribadi maupun dari pengalaman orang lain.

Sikap legislator terhadap perencanaan kesehatan di Kabupaten Bantaeng menunjukkan apresiasi yang tinggi terhadap pemerintah Kabupaten Bantaeng, khususnya ketanggapan dalam menghadapi pandemic Covid-19. Lebih lanjut, perlu diketahui bahwa legislator juga tetap memberi andil terhadap pelaksanaan program kesehatan khususnya terkait alokasi anggaran. Program yang diajukan tidak serta merta diterima oleh legislator, tetap dilakukan rasionalisasi data dengan menghadirkan data pembanding agar masalah kesehatan masyarakat benar-benar dapat terselesaikan dengan melihat prioritas masalah yang didapatkan.

Lebih lanjut, terkait dengan faktor persepsi. Persepsi merupakan pengalaman tentang 
Indar, Muhammad Alwy Arifin, Nurhayani, Nur Annisa Hamka, Amaliah Amriani. AS : Analisis Perilaku Legislator Dalam Perencanaan ....

objek, peristiwa atau hubungan-hubungan yang diperoleh dengan menyimpulkan informasi dan melampirkan pesan (Turnip, Suntono, \& Nurmalisa, 2016). Persepsi legislator terhadap perencanaan kesehatan berupa reaksi dan tanggapan yang berjalan sesuai dengan prosedur yang ada saja. Jika dilihat dari bagaimana memberikan reaksi terhadap apa yang menjadi kebutuhan masyarakat dalam bidang kesehatan, tentunya masih ada beberapa masalah kesehatan yang belum bisa terselesaikan dengan baik, mengingat adanya keterbatasan anggaran sehingga tidak semua masalah kesehatan dapat diselesaikan. Hal ini sejalan dengan penelitian yang dilakukan oleh, Parmedy (2011) bahwa persepsi legislatif terkadang sangat standar pada prosedur yang ada saja, tidak melakukan inovasi atau pengembangan sehingga cenderung tidak berkembang.

Sejalan dengan hal tersebut, pandangan Informan dalam hal tindakan terhadap perencanaan kesehatan dinilai peneliti masih dalam level normatif. Hal ini sejalan dengan hasil penelitian yang dilakukan oleh Marhaeni (2008) bahwa tindakan dalam bentuk aksi dan realisasi baik anggaran kesehatan maupun program kesehatan yang dirumuskan dalam perencanaan kesehatan oleh legislator sangat relatif dalam realisasinya. Hal ini juga dipengaruhi oleh terbatasnya ruang gerak anggota legislator yang hanya berkewenangan untuk melakukan fungsi pengawasan dan penganggaran apalagi anggaran yang dapat dialokasikan juga terbatas sehingga legislator perlu mempertimbangkan dengan baik prioritas masalah kesehatan di Kabupaten Bantaeng yang perlu diberikan anggaran lebih. Hal ini sejalan dengan penelitian yang telah dilakukan oleh (Ilham, 2013) meyatakan bahwa sikap legislator dalam hal pengambilan keputusan menyangkut program adalah sebagai pengambil kebijakan saja tidak terlibat pada unsur proses apalagi observasi awal di masayarakat.

Pembahasan terkait perencanaan kesehatan di tatanan legislator tentu tidak lepas dari kepentingan yang dibawa oleh masing-masing legislator (Hamida, 2016). Diketahui bahwa informan menyatakan hal yang lebih normatif bahwa ada persoalan kepentingan yaitu kepentingan masyarakat Bantaeng. Sisanya menyatakan bahwa kepentingan itu pasti ada, baik pribadi maupun kelompok, yang juga menjadi tujuan dalam proses legislasi dalam DPRD dalam semua aspek. Realisasi program cenderung melihat kepentingan yang ada didalamnya seperti pada kepentingan pribadi, dalam merealisasikan jumlah anggran kesehatan atau program kesehatan.

Kepentingan dalam realisasinya adalah bagaimana kemampuan aktor bernegosiasi menjadi salah satu faktor penentunya di tengah kontestasi atas banyaknya masalah yang harus dibiayai secara maksimal sementara dana yang dimiliki terbatas 
dalam sistuasi ini para aktor akan melakukan bargaining dengan mendayagunakan basis kekuasaannya untuk menguatkan daya tawar sampai pada tahapan pembuatan keputusan. Situasi seperti itu sering diistilahkan sebagai fenomena brokery dimana kepentingan substantif setiap aktor yang terlibat ternyata menyelipkan kepentingan terselubung aktor itu sendiri maupun pesanan by order aktor eksternal (Ardianto, Prisanto, Irwansyah, Ernungtyas, \& Hidayanto, 2020). Secara keseluruhan informan kepentingan DPRD adalah mewujudkan akuntabilitas publik yang baik khususnya dalam peningkatan dan pembangunan kesehatan masyarakat Kabupaten Bantaeng.

\section{SIMPULAN}

Berdasarkan hasil dan pembahasan, disimpulkan bahwa indikator pengetahuan legislator terhadap perencanaan kesehatan di Kabupaten Bantaeng berada pada kategori kurang, Disisi lain, indikator sikap, persepsi dan tindakan legislator terhadap perencanaan kesehatan berdasarkan wewenangnya sudah cukup baik, dimana legislator menunjukkan sikap, persepsi dan tindakan yang sesuai dengan wewenangnya, dalam hal ini melaksanakan fungsi penganggaran dan pengawasan walaupun jika dilihat dari aspek tahap perencanaan yang tepat, tindakan informan masih berada pada kategori kurang karena terbatasnya ruang kontribusi legislator dalam perencanaan kesehatan. Berdasarkan indikator kepentingan, terdapat kepentingan legislator dalam hal perencanaan kesehatan namun seluruhnya untuk mengakomodasi kepentingan derajat kesehatan masyarakat Kabupaten Bantaeng.

\section{UCAPAN TERIMA KASIH}

Penelitian ini dapat dilaksanakan dengan baik berkat bantuan dari berbagai pihak, untuk itu peneliti mengucapkan terima kasih kepada pihak DPRD Kabupaten Bantaeng dan PTSP Bantaeng yang telah memberikan kerjasama yang baik dalam penelitian ini

\section{DAFTAR PUSTAKA}

Ardianto, Prisanto, G. F., Irwansyah, I., Ernungtyas, N. F., \& Hidayanto, S. (2020). Praktik Lobi dan Negosiasi oleh Legislator Sebagai Bentuk Komunikasi Politik. Komuniti : Jurnal Komunikasi Dan Teknologi Informasi, 12(1), 25-39.

Ariyanti, E. (2017). Pengaruh Pengetahuan Dewan Tentang Anggaran Terhadap Pengawasan Keuangan Daerah (APBD) dengan Political Background, akuntabilitas Public dan Transparansi Kebijakan Public Sebagai Variabel Pemoderasi (Study Empiris Pada DPRD Kab.Pelalawan). Jom Fakultas Ekonomi, 4, 1295-1309. 
Indar, Muhammad Alwy Arifin, Nurhayani, Nur Annisa Hamka, Amaliah Amriani. AS : Analisis Perilaku Legislator Dalam Perencanaan ....

Bakri. (2017). Analisis Stakeholder dalam Perencanaan Kesehatan Kabupaten Wonogiri.

Fitriany, M., Farouk, H., \& Taqwa, R. (2016). Perilaku Masyarakat dalam Pengelolaan Kesehatan Lingkungan (Studi di Desa Segiguk sebagai Salah Satu Desa Penyangga Kawasan Hutan Suaka Margasatwa Gunung Raya Ogan Komering Ulu Selatan). Jurnal Penelitian Sains, 18(1), 168118.

Hamida, R. P. (2016). Dinamika Penyusunan ANggaran Daerah: Kasus Proses Penetapan Program dan Alokasi Anggaran Belanja Daerah di Kabupaten Sleman. Jurnal Penelitian Politik, 07(1). https://doi.org/10.1016/j.psychres.2014.11.019

Handoko, S. (2016). Analisis Pengetahuan dan Komitmen Politik Legislatif dan Eksekutif Terhadap Perencanaan Kesehatan di Dinas Kesehatan Provinsi DKI Jakarta.

Ilham, A. (2013). Hubungan Legilslatif dalam Proses Pembuatan Perda APBD Tahun 2013 Provinsi Sulsel. Universitas Hasanuddin.

Irawan, B. (2014). Analisis Perilaku Legislatif dan Eksekutif Dalam Perencanaan Kesehatan Di Kota Langsa Sumatra Utara. Universitas Sumatera Utara.

Kemenkes RI. (2009). Undang-Undang RI Nomor 36 Tahun 2009 tentang Kesehatan.

Marhaeni, D. (2008). Intervensi Politik dalam Pengawasan dan Penganggaran Departemen Kesehatan 2006-2007. Jurnal Manajemen Pelayanan Kesehatan, 11, 173-178. Retrieved from ejournal.unsrat.ac.id

Parmedy. (2011). Analisis Penyusunan Dan Penetapan Anggaran APBD Dinas Kesehatan Kabupaten Nunukan Tahun 2011. Makassar: Universitas Hasanuddin.

Rahman, N. (2017). Kelembagaan Legislasi Peta Jalan Politik Menuju Penguatan. Fahmis Pustaka.

Ramadhan, A. (2012). Interaksi Kepentingan Eksekutif dan Legislatif ( Study Tentang Proses Penyusunan dan Penetapan APBD bidang Pembangunan Tahun 2012 di Kabupaten Malang. Universitas Sumatera Utara.

Turnip, A. D., Suntono, I., \& Nurmalisa, Y. (2016). Persepsi Masyarakat Terhadap Peran Partai Politik Dalam Pemilihan Kepala Daerah di Desa Branti Kecamatan Natar Kabupaten Lampung Selatan Tahun 2015. Jurnal Kultur Demokrasi, 4(3).

Undang-Undang Nomor 23 Tahun 2014 tentang Pemerintah Daerah.

\begin{tabular}{|l|l|}
\hline Submission & $26-07-2021$ \\
\hline Review & $29-07-2021$ \\
\hline Accepted & $16-09-2021$ \\
\hline Publish & $29-10-2021$ \\
\hline DOI & $10.29241 /$ jmk.v7i2.653 \\
\hline Sinta Level & 3 (Tiga) \\
\hline
\end{tabular}

